\title{
PREDIKSI INDEKS STANDAR PENCEMARAN UDARA DI KOTA SURABAYA BERDASARKAN KONSENTRASI GAS KARBON MONOKSIDA
}

\author{
Mohammad Ma'Arif Syaifulloh ${ }^{1}$ \\ ${ }^{1}$ Program Studi Statistika Bisnis, Fakultas Vokasi, Institut Teknologi Sepuluh Nopember \\ e-mail: syaifulloh.maarif9@gmail.com
}

\begin{abstract}
Abstrak
Kota Surabaya merupakan pusat kegiatan dari berbagai sektor di kawasan Jawa Timur salah satunya yaitu sektor industri sehingga banyaknya lapangan pekerjaan yang tercipta. Hal ini yang mendorong masyarakat luar Surabaya untuk mencari pekerjaan di Kota Surabaya. Karena lapangan pekerjaan di Kota Surabaya menyebar, menimbulkan mobilitas masyarakat dimana transportasi sangat dibutuhkan untuk melakukan mobilitas. Jumlah kendaraan di Kota Surabaya yang berbahan bakar bensin sebanyak 2.987.437 unit dan jumlah kendaraan berbahan bakar solar sebesar 179.331 unit. Hal ini dapat mempengaruhi kondisi kualitas udara di Kota Surabaya Sehingga dilakukan penelitian tentang prediksi indeks standar pencemaran udara di Kota Surabaya berdasarkan konsentrasi CO menggunakan kombinasi metode ARIMA Box-Jenkins dan regresi linear sederhana. Hasil analisis menunjukkan bahwa model peramalan terbaik berdasarkan nilai RMSE dan MAD adalah $\operatorname{ARIMA}(1,0,0)$ dimana model peramalan tersebut telah memenuhi asumsi residual. Berdasarkan hasil ramalan, diperoleh prediksi indeks standar pencemaran udara dengan menggunakan regresi linier sederhana menunjukkan hasil prediksi tertinggi pada periode 1 Januari hingga 3 Januari 2021 sebesar 10,5401 dengan kategori baik.

Kata Kunci: ARIMA Box-Jenkins, CO, Indeks Standar Pencemaran Udara, Regresi Linier Sederhana
\end{abstract}

\begin{abstract}
Surabaya city is the center of activity for various sectors in the East Java region, one of which is the industrial sector, so that created many field jobs. That is the reason why people from outside Surabaya to looking for a job in Surabaya. The field jobs in the city of Surabaya are spreading, so transportation is crucial for people mobilities. The number of gasoline-fueled vehicles in Surabaya is 2.987.437 units, and the number of diesel-fueled vehicles is 179.331 units. The combustion of vehicle fuel produces carbon monoxide gas it can affect air quality in Surabaya. Therefore, this study was conducted on the prediction of air pollution index in the city of Surabaya based on the content of carbon monoxide air pollution using combine of ARIMA BoxJenkins method and Simple linear regression. The result analysis shows that the best model bsed on RMSE and MAD is ARIMA (1,0,0), where the forecasting model has fulfilled the residual assumptions. The regression models may explain the diversity of data at 54,6\%. Based on the forecasting results, shows that the highest prediction of the air pollution index is in the period of January 01 to January 03, 2021 amounted 10,5401 which is in a good category.

Keywords: ARIMA Box-Jenkins, Air Pollution Index, CO, Simple Linear Regression
\end{abstract}

\section{PENDAHULUAN}

Kota Surabaya menjadi pusat kegiatan dari berbagai sektor di kawasan Jawa Timur, salah satunya yaitu sektor industri sehingga banyak lapangan pekerjaan yang tercipta di Kota Surabaya. Hal ini yang mendorong masyarakat luar untuk mencari pekerjaan di Kota Surabaya. Lapangan pekerjaan di Kota Surabaya menyebar yang menimbulkan mobilitas masyarakat sehingga transportasi sangat dibutuhkan untuk melakukan mobilitas. Berdasarkan buku laporan Dinas Lingkungan Hidup Kota Surabaya pada tahun 2019, jumlah kendaraan berbahan bakar bensin sebanyak 2.987.437 unit dan jumlah kendaraan 
berbahan bakar solar sebanyak 179.331 unit. Jumlah kendaraan bermotor di Kota Surabaya pada tahun 2019 meningkat dari tahun sebelumnya (Dinas Lingkungan Hidup 2019). Hal ini memberikan dampak pada kepadatan lalu lintas dan peningkatan pencemaran udara. Menurut publikasi AQI (Air Quality Index) Air Visual pada tahun 2019, Surabaya berada di peringkat ketujuh untuk kota yang paling berpolusi dibandingkan dengan kota lainnya di Indonesia dan berada di urutan ke-226 dibandingkan kota lainnya yang ada di dunia (IQAIR n.d.). Hal ini membuktikkan bahwa kualitas udara di Kota Surabaya masih belum dikatakan baik. Untuk mengetahui kondisi kualitas udara diperlukan suatu nilai atau indeks yang menyatakan tingkat kualitas udara.

Indeks Kualitas Udara (IKU) merupakan indikator yang digunakan untuk melihat kualitas udara di suatu wilayah. IKU secara resmi di Indonesia menggunakan indeks standar pencemaran udara. Kualitas udara dikatakan baik ketika IKU memiliki rentang nilai 0-50, sedang ketika IKU berada pada rentang 51-100, tidak sehat ketika IKU berada pada rentang 101-199, sangat tidak sehat ketika IKU berada pada rentang 200-299 sedangkan berbahaya nilai IKU lebih besar dari 300. Pengukuran indeks standar pencemaran udara didasarkan pada lima parameter. Berdasarkan 5 komponen pembentuk indeks standar pencemaran udara, konsentrasi gas karbon monoksida yang paling dominan (Dinas Lingkungan Hidup 2014). Konsentrasi gas karbon monoksida mayoritas dihasilkan oleh kendaraan bermotor, pembakaran sampah, kegiatan industri dan lain lain. Dampak dari karbon monoksida sangatlah berbahaya bagi kesehatan salah satunya kerusakan jantung jika dalam jangka panjang (Dinas Lingkungan Hidup 2019).

Konsentrasi gas karbon monoksida di Surabaya berfluktuasi dari hari ke hari, sehingga indeks standar pencemaran udara juga berfluktuasi. Beberapa penelitian tentang kualitas udara antara lain tentang peramalan pencemaran udara di Kota Pekanbaru yang disebabkan oleh parameter karbon monoksida menunjukkan parameter karbon monoksida meningkat secara perlahan dari hari ke hari (Suhartati 2012). Penelitian lain tentang peramalan polusi udara dengan menggunakan vector autoregressive juga menunjukkan adanya fluktuasi (Herlinda 2013). Cai melakukan penelitian tentang analisis time series polusi udara yang disebabkan oleh karbon monoksida (CO) menggunakan model ARIMA Seasonal dan model VAR (Cai 2008). Penelitian yang telah dijelaskan diatas lebih banyak berfokus pada satu metode atau membandingkan antara dua metode kemudian memilih metode terbaik. Akan tetapi, Attanayke dkk menyatakan bahwa model ARIMA BoxJenkins dapat di kombinasikan dengan model lain yaitu model Exponential Smoothing (Attanayake et al. 2019).

Berdasarkan beberapa penelitian sebelumnya, penelitian ini ingin mengetahui prediksi indeks standar pencemaran udara berdasarkan pada konsentrasi gas karbon monoksida dengan mengkombinasikan ARIMA Box-Jenkins untuk meramal konsentrasi gas karbon monoksida dan model regresi linear sederhana untuk memprediksi indeks standar pencemaran udara berdasarkan konsentrasi gas karbon monoksida yang diperoleh dari model ARIMA Box-Jenkins.

\section{METODE PENELITIAN}

\subsection{Sumber Data}

Data yang digunakan dalam penelitian ini adalah data sekunder yang diperoleh dari Dinas Lingkungan Hidup Kota Surabaya tentang data harian indeks standar pencemaran udara dan konsentrasi CO pada udara tahun 2020. Jumlah data sebanyak 366 data untuk masing-masing variabel. Data rata-rata harian konsentrasi CO diperoleh dari pengukuran Stasiun Pemantau Kualitas Udara Ambien (SPKU). Kota Surabaya memiliki dua SPKU yang lokasinya ada di Wonorejo dan Kebonsari. Data yang digunakan pada analisis 
peramalan yaitu data rata-rata tiga harian konsentrasi karbon monoksida. Sebelum dilakukan analisis, data terlebih dahulu dibagi menjadi data insample yaitu sejumlah 98 data yang diambil secara terurut dan sisanya adalah data outsample sejumlah 24 data. Data insample digunakan untuk menganalisis dan membentuk model peramalan sedangkan data outsample digunakan untuk memvalidasi model peramalan yang terbentuk.

\subsection{Analisis Time Series}

Analisis Time Series adalah metode peramalan dengan menggunakan analisa pola hubungan antara obeservasi saat ini dengan observasi sebelumnya. Peramalan suatu data time series perlu memperhatikan tipe atau pola data. Secara umum terdapat empat macam pola data time series yaitu horizontal, trend, musiman dan siklis (Hanke and Wichern 2005). Kegunaan peramalan adalah untuk memprediksi peristiwa yang akan datang berdasarkan informasi masa lalu (Baroroh 2008). Banyak metode yang digunakan dalam peramalan data time series salah satunya yaitu metode ARIMA atau Autoregressive Integrated Moving Average. Dalam metode analisis ARIMA Box-Jenkins memiliki beberapa tahapan yaitu sebagai berikut

\section{Identifikasi Stasioneritas Data}

Suatu data time series dapat dikatakan stasioner jika tidak terjadi perubahan yang sistematis seiring berjalannya waktu baik pada rata-rata maupun variansi (Nachrowi and Usman 2004).

\section{Identifikasi Model ARIMA}

Identifikasi model ARIMA dilakukan apabila data telah stasioner. Identifikasi model didasarkan pada plot ACF dan plot PACF. Plot ACF digunakan untuk identifikasi orde model Moving Average (q), plot PACF digunakan untuk identifikasi orde model Auto Regressive (p) dan orde (d) merupakan orde differencing untuk menstasionerkan data (Wei 2005). Bentuk umum model ARIMA adalah sebagai berikut.

$$
\left(1-\emptyset_{1} B-\cdots-\emptyset_{p} B^{p}\right)(1-B)^{d} Z_{t}=\left(1-\theta_{1} B-\cdots-\theta_{p} B^{p}\right) a_{t}
$$

\section{Estimasi Parameter}

Salah satu metode yang digunakan untuk melakukan pendugaan parameter pada model ARIMA yaitu metode MLE atau Maximum Likelihood Estimation. Metode MLE melakukan pendugaan parameter $\phi$ dan $\theta$ dengan memaksimumkan fungsi likelihood . Model peramalan ARIMA layak digunakan apabila parameter signifikan dan residual bersifat white noise. Pengujian parameter dilakukan menggunakan statistic uji t sedangkan pengujian residual bersifat white noise menggunakan statistik uji Ljung-Box.

\section{Evaluasi Model Peramalan}

Evaluasi model peramalan dilakukan untuk mendapatkan model peramalan yang terbaik dari beberapa model yang sesuai. Evaluasi model peramalan dilakukan dengan melihat nilai eror paling kecil dari nilai ramalan terhadap nilai aktual. Terdapat beberapa kriteria yang digunakan untuk memvalidasi model peramalan diantaranya Root Mean Square Error (RMSE) dan Mean Absolute Deviation (MAD) (Montgomery et al. 2008). Rumus dari RMSE dan MAD yaitu sebagai berikut.

$$
\begin{gathered}
R M S E=\sqrt{\frac{1}{n} \sum_{i=1}^{n}\left(Z_{i}-Z^{\prime}{ }_{i}\right)^{2}} \\
M A D=\frac{1}{n} \sum_{t=1}^{n}\left|Z_{t}-Z_{t}^{\prime}\right|
\end{gathered}
$$




\subsection{Regresi Linier Sederhana}

Regresi Linear Sederhana merupakan model yang menyatakan bentuk hubungan antara variabel respon dan satu variabel prediktor sebagai penaksir. Dengan kata lain, analisis regresi linear sederhana adalah proses mengestimasi (menaksir) sebuah fungsi hubungan antara variabel respon dengan variabel prediktor (Walpole 2012).

\section{Estimasi Parameter dan Kelayakan Model Regresi}

Pendugaan koefisien regresi pada model regresi linier sederhana menggunakan metode Ordinary Least Square atau metode OLS. Metode OLS bertujuan untuk menemukan penduga dari parameter regresi dengan meminimumkan jumlah kuadrat residual (Montgomery et al. 2012). Uji kelayakan model regresi dilihat berdasarkan nilai statistik uji $\mathrm{F}$ hasil perhitungan pada analisis varians yang dibandingkan dengan tabel distribusi F. Model regresi layak digunakan jika nilai statistic uji $\mathrm{F}$ lebih besar dari tabel distribusi $\mathrm{F}$ (Ferdinand 2014). Koefisien determinasi $\left(R^{2}\right)$ digunakan untuk mengukur seberapa baik sebuah model regresi. Nilai $R^{2}$ berkisar antara 0 sampai dengan 1 dan model regresi dikatakan baik jika nilai $R^{2}$ mendekati nilai 1 . Nilai koefisien determinasi menyatakan persentase keragaman data respon yang dapat dijelaskan oleh data prediktor (Sudjana 2015). Pengujian signifikansi parameter dilakukan untuk melihat apakah variabel prediktor berpengaruh signifikan terhadap variabel respon (Kurniawan and Yuniarto 2016).

\section{HASIL DAN PEMBAHASAN}

\subsection{Peramalan Konsentrasi Gas Karbon Monoksida}

Untuk mendapatkan hasil ramalan kadar polutan gas karbon monoksida maka dilakukan analisis peramalan dengan menggunakan metode ARIMA Box-Jenkins.

\section{Time Series Plot}

Time series plot dilakukan dengan tujuan untuk melihat pola data dalam hal ini data insample konsentrasi gas karbon monoksida seperti ditunjukkan pada Gambar 1.

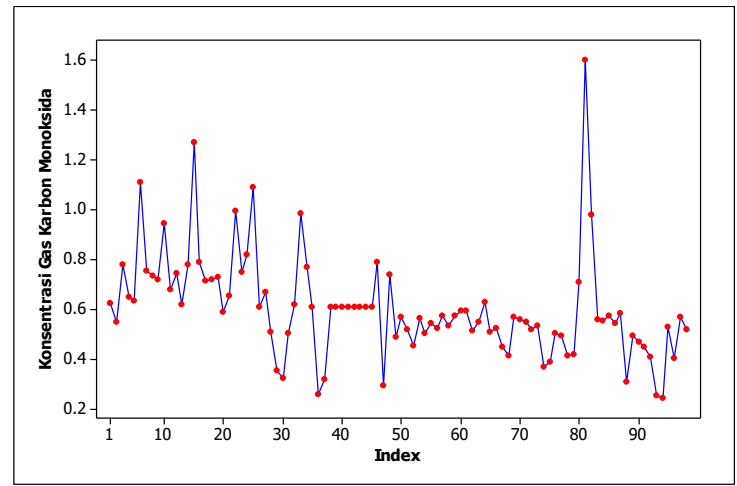

Gambar 1 Time Series Plot Konsentrasi Gas Karbon Monoksida

Gambar 1 merupakan time series plot dari data konsentasi gas karbon monoksida yang menunjukkan bahwa pola data secara keseluruhan membentuk pola trend menurun dan dapat dilihat rata-rata polutan gas karbon monoksida paling tinggi pada data ke-81 atau pada tanggal 28 Agustus 2020 hingga 30 Agustus 2020. Hal ini terjadi karena pada tanggal 28 Agustus 2020 merupakan Pembatasan Sosial Berskala Besar pertama yang dilaksanakan Kota Surabaya sehingga banyak terjadi kemacetan karena adanya penyekatan di beberapa wilayah perbatasan kota Surabaya dengan kota lain. 


\section{Identifikasi Model ARIMA}

Identifikasi model ARIMA dilakukan dengan melihat plot ACF dan plot PACF dari data yang sudah stasioner. Plot ACF digunakan untuk menduga orde model AR(p) dan plot PACF digunakan untuk orde model MA(q). Berikut merupakan plot PACF ditunjukkan pada Gambar 2.
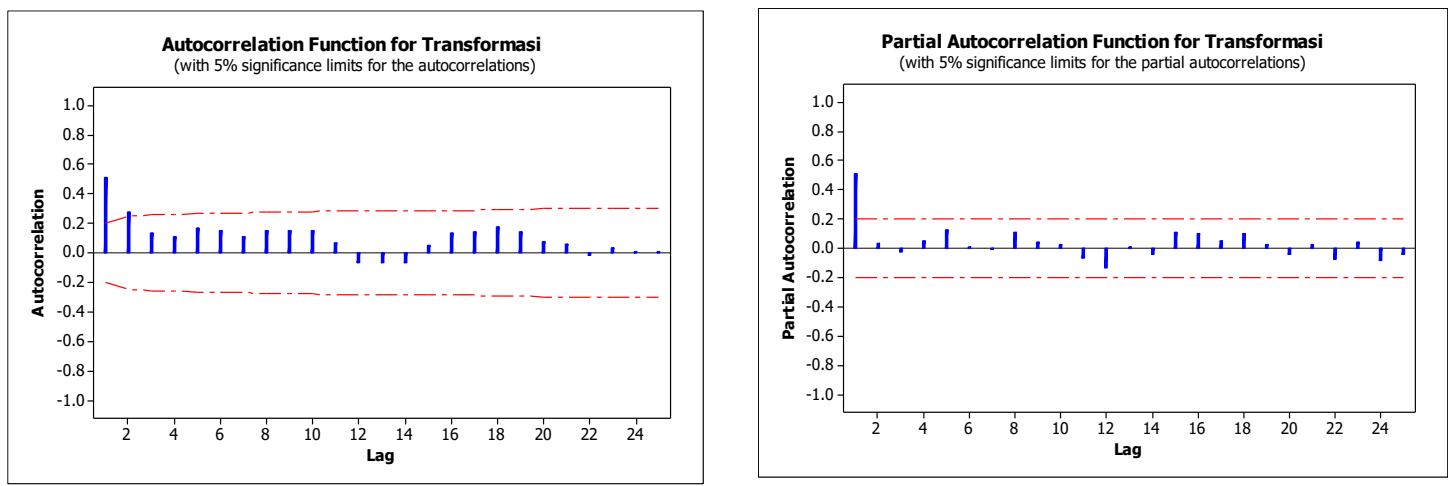

Gambar 2 Plot ACF dan PACF Data Insample Konsentrasi Gas Karbon Monoksida

Gambar 2 merupakan plot PACF data yang menunjukkan pola yang terbentuk adalah cut off setelah lag 1 sedangkan pada plot ACF yang memiliki pola turun cepat. Sehingga model dugaan adalah $\operatorname{ARIMA}(1,0,0)$. Untuk mendapatkan model terbaik dilakukan overfitiing model yaitu $\operatorname{ARIMA}(0,0,2) ; \operatorname{ARIMA}(1,0,2)$.

\section{Estimasi Dan Pengujian Signifikansi Parameter}

Estimasi dan pengujian signifikansi parameter dilakukan untuk melihat apakah parameter yang ada pada model dugaan telah signifikan atau tidak. Berdasarkan model dugaan yang terbentuk menunjukkan dengan taraf signifikan sebesar 5\% maka diperoleh hasil dari estimasi dan pengujian signifikansi parameter yang ditunjukkan pada Tabel 1 sebagai berikut.

Tabel 1 Estimasi dan Pengujian Signifikansi Parameter

\begin{tabular}{cccccc}
\hline Model ARIMA & Parameter & Estimasi Parameter & SE & T hitung & $P$-value \\
\hline ARIMA(1,0,0) & $\delta$ & 1,44594 & 0,05613 & 25,76 & $<0,0001$ \\
& $\emptyset_{1}$ & 0,50178 & 0,08791 & 5,71 & $<0,0001$ \\
ARIMA(1,0,2) & $\delta$ & 1,44594 & 0,05568 & 25,97 & $<0,0001$ \\
& $\emptyset_{1}$ & 0,40261 & 0,34582 & 1,16 & 0,2443 \\
& $\theta_{1}$ & $-0,08716$ & 0,35285 & $-0,25$ & 0,8049 \\
& $\theta_{2}$ & $-0,08929$ & 0,18883 & $-0,47$ & 0,6363 \\
ARIMA $(0,0,2)$ & $\delta$ & 1,44620 & 0,04858 & 29,77 & $<0,0001$ \\
& $\theta_{1}$ & $-0,461$ & 0,09931 & $-4,64$ & $<0,0001$ \\
& $\theta_{2}$ & $-0,25094$ & 0,09960 & $-2,52$ & 0,0117
\end{tabular}

Tabel 1 menunjukkan hanya dua model ARIMA dengan parameter yang signifikan, sehingga dua model ARIMA tersebut dilakukan pemeriksaan asumsi residual white noise dan distribusi normal.

\section{Pengujian Asumsi Residual Data}

Pengujian asumsi residual dilakukan untuk melihat apakah model dugaan ARIMA dengan parameter yang signifikan telah memenuhi asumsi residual atau tidak. Pengujian asumsi residual dibagi menjadi dua yaitu pengujian asumsi residual white noise dan 
distribusi normal. Berikut merupakan hasil dari pengujian asumsi residual data dengan taraf signifikan sebesar 5\%.

Tabel 2 Pengujian Asumsi Residual White Noise

\begin{tabular}{cccccc}
\hline \multirow{2}{*}{ Model } & \multicolumn{3}{c}{ Asumsi White Noise } & \multicolumn{2}{c}{ Asumsi Distribusi Normal } \\
\cline { 2 - 6 } & Lag & $\begin{array}{c}P \text { - } \\
\text { value }\end{array}$ & Keterangan & $P$-value & Keterangan \\
\hline ARIMA (1,0,0) & $1-6$ & 0,8421 & & & \\
& $1-$ & 0,8688 & & & Tidak \\
& 12 & & White Noise & $<0,01$ & berdistribusi \\
& $1-$ & 0,9059 & & & \\
& 18 & & & & \\
& $1-$ & 0,9589 & & & \\
ARIMA $(0,0,2)$ & 24 & & & Tidak \\
& $1-6$ & 0,4584 & & & berdistribusi \\
& $1-$ & 0,6789 & & & \\
& 12 & & White Noise & \\
& $1-$ & 0,7652 & & & \\
& 18 & & & & \\
& $1-$ & 0,8927 & & & \\
& 24 & & & & \\
&
\end{tabular}

Tabel 2 merupakan hasil uji asumsi residual white noise yang menunjukkan bahwa model ARIMA $(1,0,0)$ dan $\operatorname{ARIMA}(0,0,2)$ memenuhi asumsi white noise karena nilai pvalue yang diperoleh lebih dari 0,05 . Tetapi kedua model peramalan tidak memenuhi asumsi distribusi normal karena nilai p-value masing masing kurang dari 0,05. Hal ini bisa terjadi karena adanya data outlier yang menyebabkan pola distribusi data tidak berdistribusi normal.

\section{Pemilihan Model ARIMA Terbaik}

Tahap selanjutnya yaitu pemilihan model ARIMA terbaik pada model $\operatorname{ARIMA}(1,0,0)$ dan $\operatorname{ARIMA}(0,0,2)$ yang telah dilakukan pengujian asumsi residual. Dari kedua model ARIMA tersebut dipilih salah satu untuk dilakukan peramalan pada data kandungan polutan gas karbon monoksida untuk 12 periode kedepan. Pemilihan model peramalan menggunakan nilai eror RMSE dan MAD dimana model ARIMA yang memiliki RMSE dan MAD paling kecil merupakan model ARIMA yang terbaik. Berikut merupakan hasil dari nilai eror RMSE dan MAD pada masing-masing model yang menggunakan data out-sample.

Tabel 3 Pemilihan Model Peramalan Terbaik

\begin{tabular}{ccc}
\hline Model & RMSE & MAD \\
\hline ARIMA $(1,0,0)$ & $\mathbf{0 , 2 3 4 9}$ & $\mathbf{0 , 1 6 8 1}$ \\
ARIMA $(0,0,2)$ & 0,2354 & 0,1689
\end{tabular}

Tabel 3 merupakan hasil dari perhitungan nilai eror RMSE dan MAD pada masingmasing model yang menunjukkan bahwa model yang memiliki nilai RMSE dan MAD paling kecil adalah model ARIMA $(1,0,0)$ sehingga dapat dikatakan model $\operatorname{ARIMA}(1,0,0)$ merupakan model peramalan yang terbaik.

\subsection{Analisis Regresi Linier Sederhana}

Analisis regresi linier sederhana digunakan untuk melakukan prediksi pada indeks standar pencemaran udara berdasarkan peramalan dari konsentrasi gas karbon monoksida bagian 3.1. Data yang digunakan pada analisis regresi linier sederhana adalah data rata-rata 
3 harian pada indeks standar pencemaran udara dan konsentrasi gas karbon monoksida sejumlah 122 data.

\section{Estimasi Dan Pengujian Signifikansi Parameter Model Regresi}

Estimasi parameter model regresi tersebut diperoleh dengan menggunakan metode kuadrat terkecil. Hasil estimasi model regresi ditunjukkan sebagai berikut.

$$
Y=3,96+10,8 X+\varepsilon
$$

Berdasarkan hasil estimasi model regresi linear menunjukkan jika konsentrasi gas polutan karbon monoksida meningkat satu $\mathrm{mg} / \mathrm{m}^{3}$ maka indeks standar pencemaran udara meningkat sebesar 10,8. Model yang dihasilkan mempunyai nilai $R^{2}$ sebesar $50 \%$ yang artinya variabel gas polutan karbon monoksida mampu menjelaskan model sebesar $50 \%$ keragaman data indeks standar pencemaran udara sedangkan sisanya.

Untuk mengetahui model yang terbentuk layak digunakan atau tidak, perlu dilakukan pengujian model yaitu menggunakan uji kelayakan model. Dengan taraf signifikan 5\% menunjukkan hasil nilai $\mathrm{F}$ hitung sebesar 119,91 dimana nilai tersebut lebih besar dari $F_{(0,05 ; 1 ; 118)}$ yaitu sebesar 3,921 yang artinya model regresi layak untuk digunakan.

Mengingat model yang terbentuk layak untuk digunakan maka perlu diketahui komponen apa saja yang berperan (signifikan). Untuk itu perlu dilakukan pengujian parameter. Dengan taraf signifikan 5\% maka diperoleh hasil pengujian signifikansi parameter yang ditunjukkan pada Tabel 4.

Tabel 4 Pengujian Signifikansi Parameter

\begin{tabular}{cccc}
\hline Prediktor & $\left|t_{\text {hit }}\right|$ & $t_{0,025 ; 120}$ & $P$-value \\
\hline Konstan & 6,30 & & 0,000 \\
$\begin{array}{c}\text { Konsentrasi gas karbon } \\
\text { monoksida }\end{array}$ & 10,95 & 2,27 & 0,000
\end{tabular}

Tabel 4 menunjukkan diperoleh nilai p-value pada konstan sebesar 0,000 dimana nilai tersebut kurang dari 0,05 yang artinya variabel konstan berpengaruh signifikan terhadap indeks standar pencemaran udara. Variabel konsentrasi gas karbon monoksida memiliki nilai $p$-value sebesar 0,000 dimana nilai tersebut kurang dari 0,05 yang artinya variabel konsentrasi gas karbon monoksida berpengaruh signifikan terhadap indeks standar pencemaran udara. Tahap selanjutnya adalah pengujian asumsi residual data yang menunjukkan bahwa residual data memenuhi asumsi identik tetapi tidak memenuhi asumsi independen dan distribusi normal sehingga perlu dilakukan penanganan untuk menghilangkan kasus autokorelasi dengan memasukkan lag dari variabel respon sebagai variabel prediktor.

\section{Estimasi Dan Pengujian Signifikansi Parameter Model Regresi dengan Penambahan Lag Variabel}

Untuk menghilangkan kasus autokorelasi maka dilakukan penanganan dengan memasukkan lag variabel respon sebagai variabel prediktor. Sehingga hasil estimasi parameter yang diperoleh yaitu sebagai berikut.

$$
Y=2,07+10,2 \mathrm{X}+0,219 Y_{t-1}+\varepsilon
$$

Berdasarkan hasil estimasi parameter model regresi setelah dilakukan penanganan pada asumsi independen menunjukkan bahwa jika konsentrasi gas karbon monoksida meningkat satu $\mathrm{mg} / \mathrm{m}^{3}$ maka indeks standar pencemaran udara meningkat sebesar 10,2. Model yang dihasilkan mempunyai nilai $R^{2}$ sebesar $54,6 \%$ yang artinya variabel konsentrasi gas polutan karbon monoksida mampu menjelaskan model sebesar $54,6 \%$ 
keragaman data indeks standar pencemaran udara sedangkan sisanya dijelaskan oleh variabel lain diluar model.

Sebelum dilakukan pengujian signifikansi parameter maka dilakukan uji kelayakan model untuk melihat apakah model layak untuk digunakan atau tidak. Dengan taraf signifikan 5\% menunjukkan hasil nilai $\mathrm{F}$ hitung sebesar 71,06 dimana nilai tersebut lebih dari $F_{(0,05 ; 1 ; 118)}$ yaitu sebesar 3,92 yang artinya model regresi layak untuk digunakan.

Hasil dari uji kelayakan model menunjukkan bahwa model layak untuk digunakan, maka selanjutnya dilakukan pengujian signifikansi parameter untuk mengetahui parameter apa saja yang berpengaruh signifikan. Dengan taraf signifikan 5\% maka diperoleh hasil pengujian signifikansi parameter yang ditunjukkan pada Tabel 5 sebagai berikut.

Tabel 5 Pengujian Signifikansi Parameter Setelah Penamabahan Lag Variabel

\begin{tabular}{cccc}
\hline Prediktor & $\left|t_{\text {hit }}\right|$ & $t_{0,025 ; 119}$ & P-value \\
\hline Konstan & 2,54 & & 0,012 \\
$\begin{array}{c}\text { Konsentrasi gas karbon } \\
\text { monoksida }\end{array}$ & 10,52 & 2,2701 & 0,000 \\
Lag Variabel & 3,56 & & 0,001 \\
\hline
\end{tabular}

Tabel 5 menunjukkan bahwa menunjukkan bahwa setelah penambahan lag variabel, untuk parameter konstan tetap berpengaruh signifikan terhadap indeks standar pencemaran udara. Pada variabel konsentrasi gas karbon monoksida juga tetap berpengaruh signifikan terhadap indeks standar pencemaran udara. Lag variabel yang dimasukkan ke dalam model berpengaruh signifikan terhadap indeks standar pencemaran udara.

\section{Hasil Prediksi Indeks Standar Pencemaran Udara}

Untuk mendapatkan prediksi indeks standar pencemaran udara yang akan datang, didasarkan pada nilai ramalan konsentrasi gas karbon monoksida maka digunakan model ramalan terbaik untuk konsentrasi karbon monoksida yaitu ARIMA(1,0,0). Prediksi indeks standar pencemaran udara berdasarkan nilai ramalan konsentrasi gas polutan karbon monoksida dengan menggunakan regresi linier sederhana disajikan pada Tabel 6 .

Tabel 6 Hasil Ramalan Konsentrasi Gas Karbon Monoksida di Kota Surabaya

\begin{tabular}{|c|c|c|c|c|c|c|}
\hline Observasi & Keterangan & $\begin{array}{l}\text { Hasil ramalan } \\
\text { ARIMA }(1,0,0)\end{array}$ & Prediksi & Batas bawah & Batas atas & Kategori \\
\hline 123 & 1 - 3 Januari 2021 & 0,6157 & 10,5401 & 7,6862 & 15,7676 & Baik \\
\hline 124 & 4-6 Januari 2021 & 0,5918 & 10,4146 & 7,4148 & 16,3816 & Baik \\
\hline 125 & 7-9 Januari 2021 & 0,5794 & 10,2607 & 7,2598 & 16,3613 & Baik \\
\hline 126 & $10-12$ Januari 2021 & 0,5729 & 10,1607 & 7,1751 & 16,2653 & Baik \\
\hline 127 & $\begin{array}{c}13 \text { Januari }-15 \\
\text { Januari } 2021\end{array}$ & 0,5694 & 10,1031 & 7,1307 & 16,1904 & Baik \\
\hline 128 & $\begin{array}{l}\text { 16 Januari - } 18 \\
\text { Januari } 2021\end{array}$ & 0,5675 & 10,0711 & 7,1079 & 16,1462 & Baik \\
\hline 129 & $\begin{array}{l}\text { 19 Januari }-21 \\
\text { Januari } 2021\end{array}$ & 0,5666 & 10,0549 & 7,0948 & 16,1198 & Baik \\
\hline 130 & $\begin{array}{l}22 \text { Januari - } 24 \\
\text { Januari } 2021\end{array}$ & 0,566 & 10,0452 & 7,0892 & 16,1060 & Baik \\
\hline 131 & $\begin{array}{c}25 \text { Januari }-27 \\
\text { Januari } 2021\end{array}$ & 0,5657 & 10,04 & 7,0851 & 16,0978 & Baik \\
\hline 132 & $\begin{array}{l}28 \text { Januari }-30 \\
\text { Januari } 2021\end{array}$ & 0,5656 & 10,0379 & 7,0829 & 16,0926 & Baik \\
\hline
\end{tabular}


3 Februari - 5

0,5655

10,0364

7,0825

16,0911

Baik

$134 \quad$ Februari 2021

0,5655

10,0361

7,0822

16,0898

Baik

Tabel 6 menunjukkan bahwa hasil peramalan konsentrasi gas karbon monoksida di Kota Surabaya paling tinggi pada observasi ke-123 atau 1 Januari 2021 hingga 3 Januari 2021 sebesar 0,6157 . Hasil peramalan terendah pada observasi ke-133 atau pada tanggal 31 Januari 2021 hingga 2 Februari 2021 dan observasi ke-134 atau pada tanggal 3 Februari 2021 hingga 5 Februari 2021 yaitu sebesar 0,5655.

Hasil prediksi indeks standar pencemaran udara tertinggi pada observasi ke-123 atau pada tanggal 1 Januari 2021 hingga 3 Januari 2021 sebesar 10,5401. Dengan menggunakan selang interval $95 \%$ nilai indeks pencemaran tersebut memiliki batas bawah sebesar 7,6862 dan batas atas sebesar 15,7676. Hasil prediksi indeks standar pencemaran udara terendah pada observasi ke-134 atau pada tanggal 3 Februari 2021 hingga 5 Februari 2021 sebesar 10,0361. Dengan menggunakan selang interval 95\% nilai indeks pencemaran tersebut memiliki batas bawah sebesar 7,0822 dan batas atas sebesar 16,0898. Secara keseluruhan hasil prediksi berada pada kategori baik.

\section{KESIMPULAN}

Model peramalan ARIMA yang terbaik adalah model $\operatorname{ARIMA}(1,0,0)$ dimana hasil ramalan konsentrasi gas karbon monoksida pada periode ke-t dipengaruhi oleh konsentrasi gas karbon monoksida satu periode sebelumnya dan residual pada periode ke-t. Hasil ramalan menunjukkan terjadi penurunan gas polutan karbon monoksida di Kota Surabaya, gas polutan karbon monoksida terendah pada observasi ke-133 atau pada tanggal 31 Januari 2021 hingga 2 Februari 2021 dan observasi ke-134 atau pada tanggal 3 Februari 2021 hingga 5 Februari 2021 dimana nilainya sebesar 0,5655 dan tertinggi pada observasi ke-123 atau pada tanggal 1 Januari 2021 hingga 3 Januari 2021 yaitu sebesar 0,6138. Hasil prediksi indeks standar pencemaran udara berdasarkan kandungan polutan gas karbon monoksida selama 12 periode kedepan menunjukkan tertinggi pada periode 1 Januari 2021 hingga 3 Januari 2021 sebesar 10,5401 yang dikategorikan pada level baik.

\section{DAFTAR PUSTAKA}

Attanayake, A. M. C. H., Perera, S. S. N., and Liyanage, U. P. (2019), "Combining Forecasts of Arima and Exponential Smoothing Models," Advances and Applications in Statistics, 59, 199-208. https://doi.org/10.17654/as059020199.

Baroroh, A. (2008), Trik-Trik Analisis Statistika dengan SPSS 15, Jakarta: PT. Elex Media Komputindo.

Cai, X. H. (2008), "Time Series Analysis of Air Pollution CO in California South Coast Area, with Seasonal ARIMA model and VAR model," University of California.

Dinas Lingkungan Hidup (2014), Laporan Kegiatan Operasional dan Pengadaan Stasiun Monitoring Udara Ambien, Surabaya: Pemerintah Kota Surabaya.

Dinas Lingkungan Hidup (2019), Buku Laporan: Dokumen Informasi Kinerja Pengelolaan Lingkungan Hidup Daerah, Pemerintah Kota Surabaya.

Ferdinand, A. T. (2014), Metode penelitian manajemen: Pedoman penelitian untuk penulisan skripsi, tesis dan disertasi ilmu manajemen, Semarang: Badan Penerbit Universitas Diponegoro.

Hanke, J. E., and Wichern, D. W. (2005), Business Forecasting, New Jersey: Pearson Prentice Hall.

Herlinda, T. (2013), "Peramalan Polusi Udara Oleh Karbon Monoksida (Co) Di Kota 
Pekanbaru Dengan Menggunakan Model Vector Autoregressive (VAR)," Universitas Islam Negeri Sultan Syarif Kasim Riau.

IQAIR (n.d.). "Surabaya Air Quality Index (AQI) and Indonesia Air Pollution | AirVisual," Available athttps://www.iqair.cn/cn-en/indonesia/east-java/surabaya.

Kurniawan, R., and Yuniarto, B. (2016), Analisis Regresi “Dasar dan Penerapannya dengan R, ” Jakarta: PT. Kharisma Putra Utama.

Montgomery, D. C., Jennings, C. L., and Kulahci, M. (2008), Introduction to Time Series Analysis and Forecasting, New Jersey: John Wiley \& Sons. Inc.

Montgomery, D. C., Peck, E. A., and Vining, G. G. (2012), Introduction to Linear Regression Analysis Fifth Edition, New Jersey: John Wiley \& Sons, Inc.

Nachrowi, D., and Usman, H. (2004), "Pendekatan Populer dan Praktis Ekonometrika untuk Analisis Ekonomi dan Keuangan," The Journal of Finance, 23.

Sudjana (2015), Metoda Statistika (7th Edition), Bandung: Tarsito Bandung.

Suhartati, Y. (2012), "Penerapan metode box-jenkins untuk peramalan pencemaran udara oleh parameter karbon monoksida (co) di kota pekanbaru tugas akhir," Universitas Islam Negeri Sultan Syarif Kasim Riau.

Walpole, R. E. (2012), Pengantar Metode Statistika Edisi ke-3, Jakarta: PT. Gramedia Pustaka Utama.

Wei, W. W. S. (2005), “Time Series Analysis: Univariate and Multivariate Methods (2nd Edition)-Addison Wesley (2005).pdf,” New York: Addison Wesley. 